IZA DP No. 626

\title{
Gender Differences in Entry Wages and Early
}

\section{Career Wages}

Astrid Kunze

November 2002 


\title{
Gender Differences in Entry Wages and Early Career Wages
}

\author{
Astrid Kunze \\ IZA Bonn
}

\section{Discussion Paper No. 626 \\ November 2002}

\author{
IZA \\ P.O. Box 7240 \\ D-53072 Bonn \\ Germany \\ Tel.: +49-228-3894-0 \\ Fax: +49-228-3894-210 \\ Email: iza@iza.org
}

This Discussion Paper is issued within the framework of IZA's research area The Future of Labor. Any opinions expressed here are those of the author(s) and not those of the institute. Research disseminated by IZA may include views on policy, but the institute itself takes no institutional policy positions.

The Institute for the Study of Labor (IZA) in Bonn is a local and virtual international research center and a place of communication between science, politics and business. IZA is an independent, nonprofit limited liability company (Gesellschaft mit beschränkter Haftung) supported by the Deutsche Post AG. The center is associated with the University of Bonn and offers a stimulating research environment through its research networks, research support, and visitors and doctoral programs. IZA engages in (i) original and internationally competitive research in all fields of labor economics, (ii) development of policy concepts, and (iii) dissemination of research results and concepts to the interested public. The current research program deals with (1) mobility and flexibility of labor, (2) internationalization of labor markets, (3) welfare state and labor market, (4) labor markets in transition countries, (5) the future of labor, (6) evaluation of labor market policies and projects and (7) general labor economics.

IZA Discussion Papers often represent preliminary work and are circulated to encourage discussion. Citation of such a paper should account for its provisional character. A revised version may be available on the IZA website (www.iza.org) or directly from the author. 
IZA Discussion Paper No. 626

November 2002

\title{
ABSTRACT
}

\section{Gender Differences in Entry Wages and Early Career Wages*}

In this paper we investigate the evolution of the gender wage gap over early careers of skilled workers in Germany using administrative longitudinal data. Advantages of the data for this type of analysis are that we observe complete work and skill accumulation histories from the beginning for up to 13 years in the labour market. Descriptives show an entry wage differential of 22 percent between male and female full-time workers. The differential stays almost constant throughout the first 8 eight years in the labour market. Adopting a human capital model, we investigate the sources for the differential by the separate analysis of entry wages and early career wages.

JEL Classification: J16, J3, J7

Keywords: male-female wage differentials, human capital, entry wages, work experience

\author{
Astrid Kunze \\ IZA \\ P.O. Box 7240 \\ D-53072 Bonn \\ Germany \\ Tel.: +492283894221 \\ Fax: +492283894210 \\ Email: kunze@iza.org
}

\footnotetext{
* Helpful comments on previous versions of the paper by Christian Dustmann, Wendy Carlin, Petra Todd and participants in presentations at CIM, Aarhus, the Zeuthen workshop, Copenhagen, and the workshop on Discrimination and Unequal Outcomes organized by ADRES/CEPR/Université du Maine Conference in Le Mans are gratefully acknowledged.
} 


\section{Introduction}

In this paper we investigate entry wage differentials and the development during the early career. To perform such an analysis, one needs retrospective information on work and wages. Existing empirical studies rely mostly on survey data. Apart from common caveats of these data sets - such as measurement error problems in wages and work history variables (Bollinger, 1998) - they often suffer from the left-censoring problem of individual labour market histories. ${ }^{1}$ This makes it difficult to measure complete work histories and disentangle the factors that determine wage differentials in entry wages and the differential evolving over the career. $^{2}$

As a result, only a few studies demonstrate that a significant entry wage gap exists. For example, in Loprest (1992) for samples of 18 to 25 year old men and women of all education groups taken from the NLS ${ }^{3}$ for 1979 to 1983 an entry wage gap of about 11 percent was found. Furthermore, Dolten and Makepeace (1986) found an entry wage gap of 7 percent using a sample of U.K. graduates in 1970. We know little, however, about explanations

\footnotetext{
${ }^{1}$ Put differently, the problem is the small sample size of individual records that are not left-censored in this way, for example, in the NLSY, PSID or BHPS - see e.g Harkness (1996), Mincer and Polachek (1974) O’Neill and Polachek (1993), Blau (1998), Light and Ureta (1995).

${ }^{2}$ Instead, studies identify entry wages parametrically by the constant in the wage regressions.

${ }^{3}$ The National Longitudinal Survey conducted in the U.S..
} 
for this entry gap and whether it persists over careers. The evolution of the male-female wage gap over the early career was examined in Light and Ureta (1995) who estimated wage regressions that included, apart from standard characteristics, controls for previous work history and time periods spent out of work. They found that about 7 percent of the wage gap can be explained by male-female differences in the timing of work experience. Evidence from the $70 \mathrm{~s}$ and $80 \mathrm{~s}$ in the U.S. seems to suggest an increasing gap that is partly attributed to lower levels of actual work experience of women compared to men, and relatively higher returns to work experience for men. (Corcoran and Duncan (1979), Polachek and Robst (2001)) As an explanation of the widening of the gap during the first four years of the career, Loprest (1992) showed that for men, wage gains from job changes are larger than for women ${ }^{4}$. Apart from this factor, she argues that occupational segregation and change from full-time work to part time work of women contribute to the increase of the wage gap.

In our study, we use a sample of young skilled full-time workers drawn from the German employment statistics, the IABS, for the period 19751990. The IABS is an administrative data set. Skilled workers are defined as workers who have undertaken vocational training within the dual system apprenticeships programme. Typically, they have completed 9-10 years of schooling and 2-3 years of apprenticeship. The sample contains approxi-

\footnotetext{
${ }^{4}$ Her results show that men are as likely as women to change job.
} 
mately the middle 70 percent of the German workforce skill distribution. The main advantages of our data are that work histories are observed from age 16 onwards, and that the sample is large, including approximately 35 000 individuals in total. Thus, precise measures of work histories, skill and wages can be generated for a significant part of the German labour force.

The goal of this paper is to disentangle the dynamics underlying the evolution of the gap. Adopting the human capital model (Becker, 1964), we distinguish factors explaining the entry wage gap and early career gap. An important factor that can explain wage differentials are premarket factors (Neal and Johnson (1996)). We use the fact that we observe entry wages and rich information on training before entry into the labour market to scrutinize the sources for wage variation. In our analysis of early career wages we condition on the complete work history. Descriptives show that among workers in their 20s gender differences in accumulated work experience are not revealed yet. Hence, holding other factors constant, differences in wages can only be accounted for by differences in the coefficients of work experience or the timing of work experience accumulation (Mincer and Polachek (1974), Mincer (1964)) as it has been pointed out in Light and Ureta (1995) for the U.S.. To analyse the impact of timing of work experience we estimate wage regressions where we use the entire path of human capital accumulation and allow coefficients to vary across work history segments. 
Three main sets of results are presented in this paper: First, we document a substantial wage gap of about 23 percent in entry wages which remains quite constant over early working careers. Second, holding occupational qualification constant ( i.e. the observed apprenticeship occupation) reduces the gap to 8.4 percent. Third, decomposition of the wage gap shows that the timing of working career accounts for 1 percent during the first couple of years of work and increases to 3 to 5 percent at 9 years of experience.

The remainder of the paper is structured as follows: In section 2, we describe the data and the institutions of apprenticeship training. In section 3, we show descriptives. The main empirical analyses on entry wages follows in section 4 and on early career wages in section 5 . In section 6 , we conclude.

\section{$2 \quad$ Data and institutional settings}

We use the IAB employment sample $(\mathrm{IABS})^{5}$ for West-Germany that is available for the period 1975 to 1990 and is an administrative event history data set. The IABS is a 1 percent random sample drawn from the event history data file of the social security insurance scheme, the employment statistics, collected by the German Federal Bureau of Labour. The fact that the data was collected for administrative purposes is an obvious advantage and makes the data particularly reliable. The IABS contains all workers in

\footnotetext{
${ }^{5}$ IABS abbreviates the Institut für Arbeitsmarkt und Berufsforschung Sample.
} 
West-Germany who have had at least one employment spell eligible for the social security insurance scheme. As a result, included are all dependent employees in the private sector, i.e. about 80 percent of total employment in West-Germany. ${ }^{6}$ The event history data includes information on every change in working status distinguished into full-time work, part-time work, unemployment, interruption which captures national service and maternity - or parental - leave, and gaps. This we summarize as time out of work in the following. One may note, also, the particular event history data structure implying that a unit of the data is a spell, which is not necessarily the same as a yearly spell. A unique feature of our data is that complete schooling, and work skill accumulation work histories are observed. This allows precise characterization of human capital characteristics.

From the IABS we generate a sample of young workers who have undertaken vocational training within the German dual system apprenticeship programme, the main route into the labour market for decades. Our sample drawn from the IABS contains only records on young workers, who have mostly, approximately 90 percent, graduated from school after 10 years of schooling and who are observed after entry into apprenticeship, i.e. age 16-22 with a mean age 20. Hence, by construction we do not have "left-

\footnotetext{
${ }^{6}$ Not included are: civil servants, self-employed, unpaid family workers and people who are not eligible for benefits from the social security system. For more details see Bender et al. (1996).
} 
censoring" of work histories problems common in labour economics. In practice apprenticeship takes 2 to 3 years. In the data individuals are followed over early careers, i.e. the oldest individuals are 30 and the mean age is 23 . Wages in the IABS are reported on a daily basis and are highly reliable given that they are checked by both data collectors and employees. However, hours of work are not reported. By focusing on full-time workers, we mitigate this short-coming. ${ }^{7}$ Extraction of these workers ${ }^{8}$ from the IABS leaves us a sample containing 14563 female workers and 19710 male workers who are observed in at least one full-time working spell after completion of vocational training. In total the number of spells in the sample of females are 87254 and in the sample of males 125782 .

Over recent decades approximately 60 to 70 percent of each birth cohort have been vocationally trained. This training programmes combines school and work-related training. Apprenticeship programmes can be found in all German speaking countries, and in variations in other countries, such as Britain, where there are also strong interests in its revival. During the

\footnotetext{
${ }^{7}$ This rule leads to exclusion of less than 3 percent of spells for males and 18.6 percent for females as can be seen from the table in the appendix. Hence, this is unlikely to induce selection bias to our estimates.

${ }^{8}$ In summary, the selection rules we apply are that the individual is not older than 15 years in 1975, the individual has undertaken training for at least 450 days without interruption, the individual has never been working part-time or home-work (e.g. family business) and the individual must be observed in the data before 1988 for the first time.
} 
period of 1975 to 1990, apprenticeships could be undertaken in about 350 occupations, ranging from technical to service occupations and in all sectors, including large or small, private or public firms of the economy. Typically, after ten years of schooling 60 percent of youth enter apprenticeship training, which lasts 2 to 3 years. Apprentices have an apprenticeship contract with the firm they are trained with; wages amount to about 20-30 percent of the wage of a skilled blue or white collar worker. In order to receive a certificate about the particular qualification acquired, apprentices have to pass written and oral examinations, and practical exercises in craftsmanship. ${ }^{9}$

\section{Descriptive statistics}

In our data, individuals are organized by cohorts according to the year of entry into apprenticeship. This is illustrated in Figures 1 and 2 where postapprenticeship employment rates for male and female workers are shown. The year of entry varies within cohorts due to variation in the age at entry into apprenticeship and duration of apprenticeship. ${ }^{10}$ As expected, males' employment rates monotonously increase to a level of 80 to 90 percent. The employment rates of females increase first, and then decrease below a

\footnotetext{
${ }^{9}$ For a detailed description of the German dual system apprenticeship programme see Münch (1992).

${ }^{10}$ For a few individuals we observe wages for working in a job eligible to social security prior to apprenticeship. We drop these unskilled work wages from our analysis sample.
} 
75,77 , etc. indicate Start of Apprenticeship

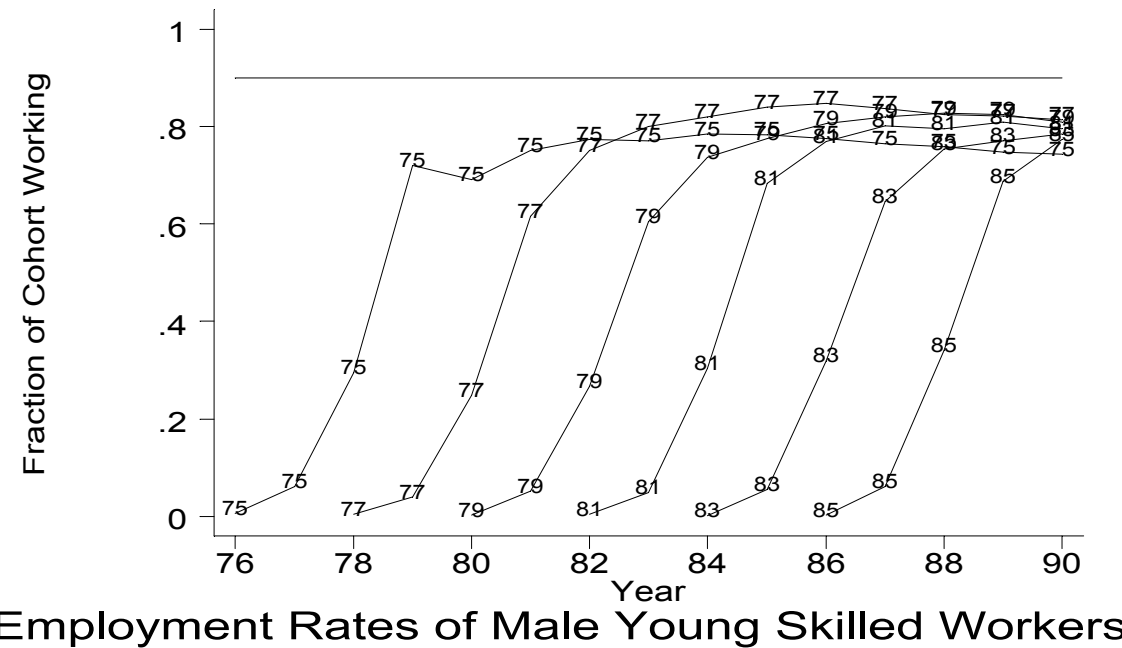

Figure 1:

population average, i.e. approximately 55 percent in 1988 for Germany ${ }^{11}$, due to child bearing and rearing. For a longer sample, one would expect employment rates to go up again.

The main variables are the wage, the work history variables work experience, total time out of work and variables measuring occupation and skill. The wage variable is the logarithm of the daily wage deflated by the consumer price index by the German Statistical Office. Due to the restriction to full-time workers, wages refer to full-time wages meaning that working hours are at least 35 hours per week. We define the variable time out of work as the total time not in salaried work, eligible to social security. It can be directly generated as the sum of days in unemployment, interruptions

\footnotetext{
${ }^{11}$ German Statistical Yearbook, various years.
} 
75,77 , etc. indicate Start of Apprenticeship

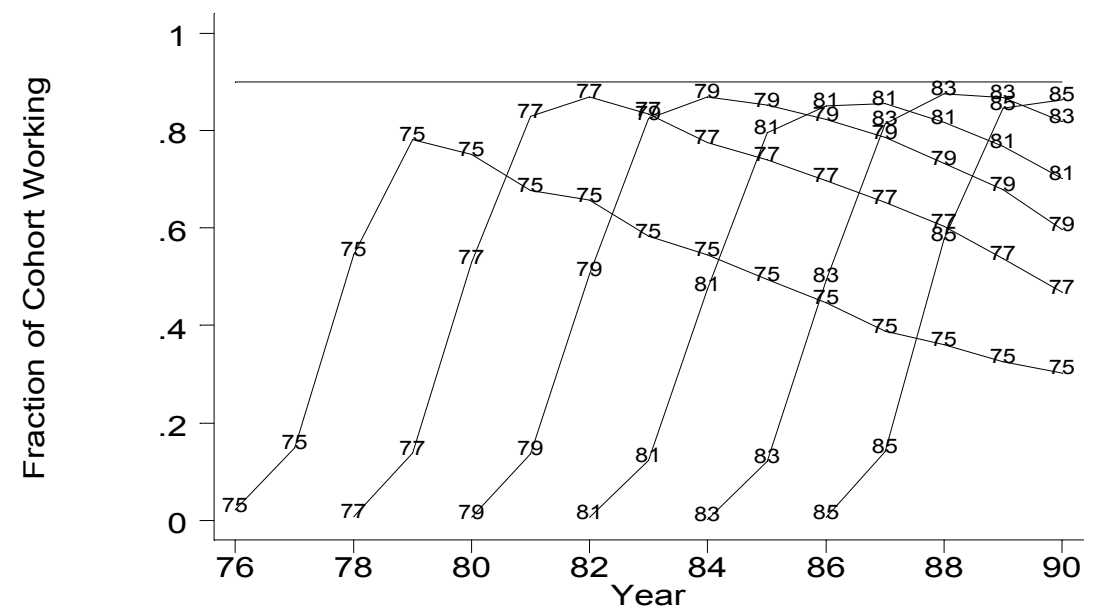

Employment Rates of Female Young Skilled Workers

Figure 2:

and non-work. Unemployment is reported in the data when individuals receive unemployment insurance. Interruption periods capture national service for men, that is compulsory for 12 months for men, and maternity leave for women, that can take 2 to 15 months at maximum. Non work spells are gaps between spells and capture periods out of work due to other reasons than unemployment or maternity leave. ${ }^{12}$

Table 1 reports raw male-female wage differentials using apprenticeship wages $^{13}$ and entry wages ${ }^{14}$. It can be seen that while men and women are

\footnotetext{
${ }^{12}$ This variable also incorporates, for example, further education, self-employment and employment not eligible to social security, i.e. jobs paid less than a lower social security threshold that was 350 German Mark per month in 1975 and 470 German Mark in 1990.

${ }^{13}$ Apprenticeship wages are measured in the last year (spell) of training.

${ }^{14}$ For technical reasons, starting wages are measured in the second wage spell of an individual's record in full-time employment. While for firm movers (immediately after apprenticeship) the end of apprenticeship is reported precisely in the data, for firm stayers
} 
Table 1: Differentials in log apprenticeship wages and log starting wages

\begin{tabular}{l|cccc}
\hline \hline & $\begin{array}{c}\text { women } \\
\text { mean } \\
(\text { std. })\end{array}$ & $\begin{array}{c}\text { men } \\
\text { mean } \\
(\text { std. })\end{array}$ & $\begin{array}{c}\text { gap } \\
\text { t-statistics for } \\
H_{0}: \text { Equality } \\
\text { of means }\end{array}$ \\
\hline $\log$ (apprenticeship wage) & 2.8312 & 2.8764 & 0.045 & -11.4 \\
& $(.3628)$ & $(.3483)$ & & \\
$\log$ (starting wage) & 3.7531 & 3.9772 & 0.2241 & -63.79 \\
& $(.3093)$ & $(.3178)$ & & \\
$\#$ of individuals & 13864 & 18928 & & \\
\hline \hline
\end{tabular}

still in apprenticeship only a very small, yet significant, differential of 4.8 percent is observed. ${ }^{15}$ By the time of first full-time employment, however, this differential has increased to 22.4 percent.

In Figure 3, we plot logarithmic wages as a function of actual work experience. Work experience is measured in the data on a daily basis. Figure 3.1a and 3.1b report logarithmic wages estimated non-parametrically as a function of work experience. ${ }^{16}$ We apply a robust smoothing method and display results for two different smoothing parameters. It appears that wage experience profiles for men and women are slightly concavely shaped and the end of apprenticeship can only be determined with variation of up to one year. Therefore, the first wage spell for stayers may contain apprenticeship wage components and a too low wage in full-time employment may be reported in the IABS. In order to make work histories comparable for firm stayers and movers we drop the first wage reported for each worker.

${ }^{15}$ The differential becomes negligibly small, i.e. 1.3 percent, after the duration in apprenticeship has been taken into account. On average the duration is longer for men, as can be seen from Table 2 .

${ }^{16}$ Wages shown here are predicted logarithmic real wages after growth due to time dummy variables has been netted out. Time dummy coefficients are estimated consistently from entry wage spells separately for males and females. Confidence bands not shown in the graph are rather narrow, given the number of observations, and wages are significantly different across work experience levels as well as gender. 

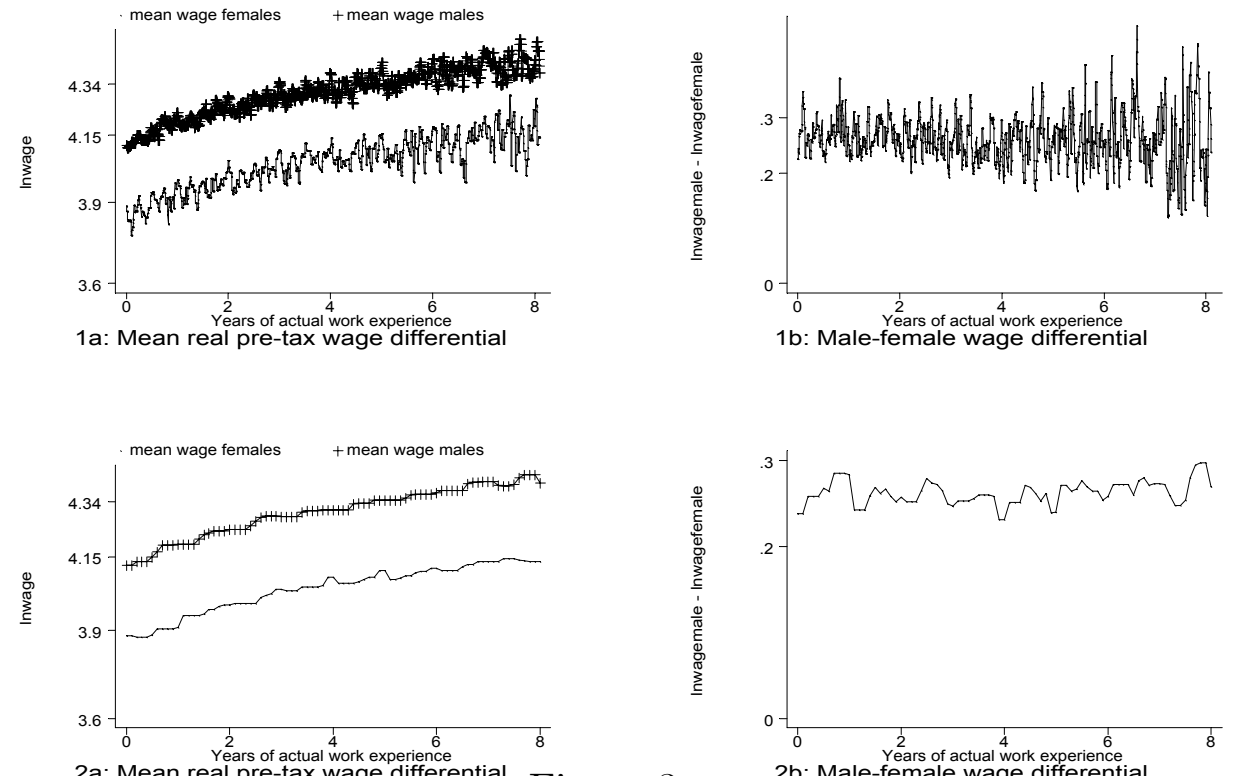

Figure 3:

develop in almost parallel fashion. The differential, accordingly, stays almost constant during this period and fluctuates around 0.23. This finding seems to contrast results shown for the U.S. in which an increase from a lower inital level has been shown. (Loprest (1992), Light and Ureta (1995))

\section{Entry wages and premarket factors}

We conduct the analysis of entry wages for the sub-sample of wages in the first job. It follows from a human capital theory approach that differentials in entry wages between genders are due to the relatively larger human capital endowment males have acquired by entry into first employment, in comparison to females. First of all, human capital in the beginning of the career can be described by (general) education, age and qualification - vocational or college degree. The corresponding mean characteristics for our 
Table 2: Sample means for males and females at entry wage spell, training cohorts 1975 to 1988

\begin{tabular}{|c|c|c|c|c|c|}
\hline & \multicolumn{2}{|c|}{ female } & \multicolumn{2}{|c|}{ male } & \multirow{2}{*}{$\begin{array}{l}\text { t-test for } \\
H_{0}: \\
\text { Equality } \\
\text { of means }\end{array}$} \\
\hline & mean & (std.) & mean & ( std.) & \\
\hline age at entry into training & 16.9467 & $(1.2888)$ & 16.5559 & $(1.1552)$ & 28.8 \\
\hline age in first job & 20.3416 & $(1.5725)$ & $\begin{array}{l}20.5000 \\
\text { education }\end{array}$ & $(1.5815)$ & -9.18 \\
\hline 1 if interm. degree & .9547 & $(.2078)$ & .9814 & $(.1350)$ & -14.37 \\
\hline 1 if Abitur * & .0453 & $(.2078)$ & .0185 & $(.1350)$ & 14.37 \\
\hline apprentice. duration & 2.18 & $(.7318)$ & 2.51 & $(.7418)$ & -40.96 \\
\hline \multicolumn{6}{|l|}{ occupational qualification**: } \\
\hline Natural products production & .0187 & .1356 & .0280 & $(.1649)$ & -5.53 \\
\hline Extraction of natural resources & .0 & $(.0)$ & .0090 & $(.0946)$ & -11.5 \\
\hline Investment goods production & .0138 & $(.1166)$ & .0846 & $(.2783)$ & -28.88 \\
\hline Consumer goods production & .0636 & $(.2441)$ & .0887 & $(.2844)$ & -8.58 \\
\hline Construction & .0054 & $(.0739)$ & .1702 & $(.3758)$ & -52.15 \\
\hline Installment of technical machines & .0247 & $(.1552)$ & .3548 & $(.4784)$ & -80.20 \\
\hline Services & .8542 & $(.3528)$ & .2105 & $(.4076)$ & 152.87 \\
\hline \multirow[t]{2}{*}{ Infrastructure services } & .0193 & $(.1378)$ & .0539 & $(.2258)$ & -16.35 \\
\hline & \multicolumn{5}{|c|}{ skill related variables } \\
\hline \multicolumn{6}{|l|}{ job status: } \\
\hline unskilled & .0896 & $(.2856)$ & .1786 & $(.3831)$ & -23.62 \\
\hline skilled blue collar & .1481 & $(.3552)$ & .6483 & $(.4775)$ & -106.47 \\
\hline other (foreman) & .0004 & $(.0219)$ & .0009 & $(.0310)$ & -1.60 \\
\hline skilled white collar & .7617 & $(.4260)$ & .1720 & $(.3774)$ & 135.31 \\
\hline \multicolumn{6}{|l|}{ skill match variables ${ }^{* * *}$ : } \\
\hline 1 if Qual.stayer & .7367 & $(.4404)$ & .6551 & $(.4753)$ & 16.20 \\
\hline 1 if Firm stayer & .6368 & $(.4809)$ & .7015 & $(.4576)$ & -12.64 \\
\hline 1 if Firm+qual.stayer & .5301 & $(.4991)$ & .5295 & $(.4991)$ & .11 \\
\hline 1 if Industry stayer & .7950 & $(.4036)$ & .7983 & $(.4012)$ & -.7345 \\
\hline \# of individuals & 13864 & & 18928 & & \\
\hline
\end{tabular}

Note: * In Germany, the Abitur school degree takes 13 years and qualifies for university. ** For calculations, the occupation of qualification classifications of the last spell in apprenticeships are used. Groups are constructed according to Dietz (1988). ${ }^{* * *}$ Definition of skill match variables: Qual. stayer: stayer in occupation of qualification (apprenticeship) measured at 3-digit level. Firm stayer: stayer with training firm. Firm + qual. stayer: stayer in occupation of qualification and training firm. Industry stayer: stayer in industry measured at 2-digit level. 
sub-samples of female and male workers are presented in Table 2. It turns out that females and males are both of similar age in their first employment. Furthermore, young skilled workers are homogeneous with respect to education; virtually all of them have an intermediate secondary schooling degree, i.e. 10 years of schooling (Haupt-or Realschule). They are also homogeneous with respect to type of tertiary education since all of them have undertaken an apprenticeship programme lasting on average 2.18 years for females and 2.51 years for males at the mean. This does imply that males should receive a higher wage to compensate for the extra 0.33 years of training.

Despite similarities of the quantity of education and vocational training among workers in our sample we find - not unexpectedly - more striking differences in the type of training, i.e. occupational qualification. Similarly to other Western industrialized countries, women are more likely to be qualified in services, for example, as a professional clerical worker or receptionist, and men are more likely to do apprenticeships in manufacturing, for example, as a motor vehicle mechanic or electrician. Hence, in analysing entry wage differentials in our sample particular attention is attributed to differences in occupational qualification - which is the main source of heterogeneity in human capital across individuals. 


\subsection{First jobs and skill}

Heterogeneity in qualification can be measured in the data in several ways. First, our data sample includes a broad measure for job status that distinguishes between unskilled, skilled blue collar workers, skilled white collar workers and others, e.g. foremen. Percentages of men and women in each of the categories are listed in Table 2. For example, 76.2 percent of women work in white collar jobs, whereas 64.8 percent of men work in blue collar jobs. Perhaps striking in international comparison, however, is that about 70 percent of all workers are categorised as skilled which implies that almost 50 percent of the entire population are categorized as (occupationally) skilled at the young age of $20 .{ }^{17}$

Second, and in contrast to most other data sources, skill can be observed (a) because the records contain individual spells while in apprenticeship and in employment afterwards and (b) because for each of the spells information on the three-digit occupation is given. Hence, skill can be measured by the occupation of qualification itself, which is the occupation reported while in apprenticeship, and by matching the occupation of qualification and the occupation of work. The latter is particularly informative about transferable human capital components. Likewise, skill with respect to firm and industry

\footnotetext{
${ }^{17}$ To do this calculation one needs to keep in mind that about $60-70$ percent of the population in Germany undertakes apprenticeships (Münch, 1992). In comparison, in the U.K. for the period 1990-1992 GHS data shows that only 27.9 percent of all male and 19.4 percent of all female aged 25-34 reached a degree or a higher educational level. See: Harkness (1996).
} 
specific human capital can be measured by comparison of the corresponding firm ${ }^{18}$ and industry ${ }^{19}$ identifiers in the data.

To describe skill match with respect to occupation, firm and industry, we generate binary skill match variables that take the value one if an individual stays and zero otherwise. Stayers with respect to occupation, for example, are defined as individuals for which the occupation of qualification on a three digit level is the same as the occupation of work. For the skill match variables, the means and standard deviations are reported in the lower panel of Table 2 .

Quite striking are the extremely high shares of stayers, in particular, in the occupation of qualification, i.e. 73 percent for females and 65 percent for males, and with the training firm, 63 and 70 accordingly. High shares of stayers may suggest that one finds positive returns for staying and losses for moving between firms, jobs (occupations) or industries due to non-transferability of human capital. Our wage regression estimates, shown in the next section, support this hypothesis.

\subsection{Entry wage regressions}

In order to estimate the explained male-female differential in entry wages, we adopt a two step procedure. In the first step, we estimate wage re-

\footnotetext{
${ }^{18}$ Firm identifiers are given to each establishment in the IABS. Large firms are split into establishments with different firm identification numbers.

${ }^{19}$ Industries are distinguished into approximately 99 groups (2-digits). The category refers to the main sector of value addition.
} 
Table 3: Log wage regressions for entry wages by sex

\begin{tabular}{l|rr|rr}
\hline \hline Variable & males & females & males & females \\
& & & & \\
\hline firm stayer & 0.0945 & 0.1004 & 0.0600 & 0.0411 \\
& $(12.33)^{* *}$ & $(10.32)^{* *}$ & $(8.51)^{* *}$ & $(5.02)^{* *}$ \\
qual. stayer & -0.0271 & -0.0271 & -0.0371 & -0.0869 \\
& $(3.25)^{* *}$ & $(3.29)^{* *}$ & $(4.82)^{* *}$ & $(12.49)^{* *}$ \\
firm + qual. stayer & 0.0127 & -0.0121 & 0.0035 & 0.0346 \\
& $(1.23)$ & $(1.04)$ & $(0.37)$ & $(3.60)^{* *}$ \\
training duration & 0.0669 & 0.0511 & 0.0641 & 0.0408 \\
& $(20.61)^{* *}$ & $(14.52)^{* *}$ & $(19.66)^{* *}$ & $(13.08)^{* *}$ \\
age at entry & 0.0161 & 0.0620 & 0.0186 & 0.0241 \\
& $(7.54)^{* *}$ & $(29.40)^{* *}$ & $(9.23)^{* *}$ & $(13.18)^{* *}$ \\
Abitur & 0.0925 & 0.1367 & 0.0652 & 0.0556 \\
& $(5.47)^{* *}$ & $(11.03)^{* *}$ & $(4.09)^{* *}$ & $(5.30)^{* *}$ \\
Constant & 3.5294 & 2.5818 & 2.9801 & 2.9903 \\
& $(91.28)^{* *}$ & $(67.48)^{* *}$ & $(75.61)^{* *}$ & $(60.85)^{* *}$ \\
Occupation qualification & & & & \\
dummy variables included & no & no & yes & yes \\
Year dummy variables & yes & yes & yes & yes \\
Observations & 18928 & 13864 & 18928 & 13864 \\
Adjusted R-squared & 0.07 & 0.15 & 0.26 & 0.44 \\
\hline \hline
\end{tabular}

Note: The dependent variable is the log of daily real wages in the first job after training. The wage observations come from 1980 to 1990 . The omitted year is 1980 . The omitted school degree is 10 years of schooling. Absolute value of t-statistics in parentheses * significant at 5 percent level; ${ }^{* *}$ significant at 1 percent level. For occupation qualification 241 dummy variables are included. Coefficients are not shown here.

gressions controlling for premarket characteristics separately for male and female workers. In the second step, we decompose the wage differential, following Oaxaca (1973) and Blinder (1973), into the explained part by the sum of the differences in human capital characteristics weighted by prices, and a residual, which is the unexplained fraction. We use the estimated coefficients from the male sample regression for the weights. The main results do not change using the female sample regression results instead.

Estimation results shown in Table 3 are very much in line with human 
capital theory. Yet, we find significant differences between groups. In column 1 and 2, estimation results are shown for wage regression where the controls for productivity related differences exclude the occupational qualification variables. Coefficients shown in column 3 and 4 are conditional on the complete array including controls for the specific training. Results seem to change very little moving from the shorter to the longer specification. We find that staying with a firm leads to wage gains compared to moving. This become smaller after taking out heterogeneity due to type of training. Changing qualification seems to decrease wages. The duration of apprenticeship is positively correlated with wages proxying perhaps quality of training. An upper degree also leads to gains that seem partly correlated with the occupational qualification.

Results for the decomposition of the entry wage gap into explained and unexplained fractions due to differences in endowments are summarised in Table 4. As shown before, the total entry wage gap is 22.4. Using the male wage regression estimates of the parameters and human capital characteristics excluding occupational qualification, as shown in column 1 and 2 in Table 3, we find that only 8.6 percent can be explained by the variables. This fraction increases to 89.9 percent if we add the occupational qualification, using results in column 3 and 4 . Hence, premarket differences play a crucial role for wage differentials. 
Table 4: Decomposition of male-female entry wage gap

\begin{tabular}{l|cc}
\hline \hline Variables & Explained & Unexplained \\
\hline $\begin{array}{l}\text { Premarket characteristics excluding oc- } \\
\text { cupational qualification }\end{array}$ & $8.6 \%$ & $91.4 \%$ \\
$\begin{array}{l}\text { Premarket characteristics including oc- } \\
\text { cupational qualification }\end{array}$ & $89.9 \%$ & $10.1 \%$ \\
\hline \hline
\end{tabular}

Note: Calculation of the decomposition follows Blinder (1974), Oaxaca (1974). We use the male sample regression results from table 2 .

A concern is that the exogeneity assumption of occupational qualification is not justified. Endogeneity due to unobserved heterogeneity across individuals, however, seems to us not a severe problem since this would imply that women are less "able" in the majority education group of the population than men. More interesting is whether the controls for occupation remove discriminatory factors in addition to productivity differences.

Selection in our sample takes place two to three years before entry into first employment, or the age of 16 . We focus on the group of juveniles who transfer from school to apprenticeship. Selection at this stage is characterised by the choice of the type of qualification. In our sample, the drop out rate for those finishing apprenticeship training is close to zero and low mobility with respect to occupation can be observed althrough the early career. This leads to the question why we observe a high degree of occupational segregation.

The concern is that the segregation is determined by discriminatory forces. This would bias outcomes and implies that our estimate of the explained 
differential would be estimated with upward bias, and, hence, the unexplained with downward bias. Entry barriers, societal rules or images that pupils are taught at school and by their parents can have effects. These discriminatory forces may result in females from being discouraged of going into male jobs, such as manual jobs or jobs in science. However, in order to explain male-female wage differentials one must then assume that male occupations generally are more profitable. While the argument in favour of discrimination may be very intuitive, though hard to measure directly, the latter is less straightforward. Also the human capital model shows that females who may anticipate more interruptive working careers maximize their lifetime earnings by choosing occupations with relatively low training content, and in which interruptions are penalized less heavily. (Polachek (1981)) All these arguments may apply to our case. This is particularly true for the very young, 16 to 18 year olds, who choose a career. Their choices may be much stronger determined by teachers, parental wishes, and societal norms, than choices at a later stage.

\section{$5 \quad$ Early career wages}

For the analysis of the wage determination process we adopt the human capital model by Mincer and Polachek (1974) that segments the work history into work experience spells and non-working spells. Their model allows to estimate the particular effect of each work history segment, and hence 
considers timing. Furthermore, it allows to give a structural interpretation to the key parameters, i.e. the coefficients of the work experience variables and non-work variables. The parameters measure the net effect of the return to and depreciation of human capital.(Mincer (1974) The empirical implementation is adopted from Light and Ureta (1995).

We estimate a work history model, as specified in equation (1),

$$
\ln w_{i t}=\beta_{0}+\sum_{s=t}^{s=t-6} e x_{i s} \beta_{1 s}+\sum_{s=t}^{s=t-6}{ }_{\text {out }} \beta_{i s} \beta_{2 s}+Z_{i} \beta_{3}+\nu_{i}+u_{i t}
$$

where $i$ indexes individuals and $t$ time. The dependent variables is logarithmic wages. The controls for the complete work history are defined for individual $i$ as an array of experience variables, $e x_{i s}$, that measure the fraction of time worked in the most recent year year, $s=t, 1$ year ago, $s=t-1$, 2 years ago, and so forth, back to the beginning of the career. These fractions can take the value zero either if the worker worked zero days during the year ago or the career was not in progress. In addition, we define dummy variables for time out of work, out, taking the value 1 if the workers did not work during the entire year. In addition, we control for premarket characteristics that are time invariant, denoted by $Z . \nu_{i}$ is an unobserved individual specific effect and $u_{i t}$ idiosyncratic noise. We allow effects to vary for up to six years into the past. ${ }^{20}$

The model is estimated by fixed effects estimation for the sample of males

\footnotetext{
${ }^{20}$ Hence, we assume that the coefficients are equal for 6,7 etc. years ago. Tests do confirm that effects further in the past do not vary significantly.
} 
and females separately. Fixed effects takes account of unobserved heterogeneity that is likely to bias coefficients of the work history variables. This results in consistent estimates of the effects on accepted wages. If selection into work for females follows a time dependent process estimates are not consistent estimates of the effects on offered wages. Comparison of estimates for our sample of females (including drop outs) and a sample of more continuously working females shows that coefficient estimates are highly sensitive to the use of the sample. In the fixed effects estimation results, that we present, we do not control for time varying non-random selection into work. However, this does not limit the results on the explained fraction of the gender wage gap due to timing of work experence since we do not rely on female sample parameter estimates.

\subsection{Summary statistics}

From the summary statistics reported in Table 5, we can see that the early careers of young skilled males and females do not reveal yet the gender distinctive labour force participation patterns. At the mean individuals in our sample have approximately six years of potential experience. In fact, females in our sample, who work 3.7 years on average measured in their last spell, seem to work even slightly more than men do. ${ }^{21}$ Comparison of total time out of work years for females and males in their last wage spell shows

\footnotetext{
${ }^{21}$ However, calculating means of work experience only for early (apprenticeship) cohorts in the sample, would make apparent that men work more years than women.
} 
Table 5: Sample means for early career, training cohorts 1975 to 1988

\begin{tabular}{|c|c|c|c|c|}
\hline & \multicolumn{2}{|c|}{ women } & \multicolumn{2}{|c|}{ men } \\
\hline & mean & (std.) & mean & ( std.) \\
\hline & \multicolumn{4}{|c|}{ all spells } \\
\hline age & 22.9462 & 2.5532 & 23.4441 & 2.7069 \\
\hline work experience & 2.5300 & 2.3224 & 2.4747 & 2.3078 \\
\hline time out of work & .3174 & .7473 & .9620 & 1.1869 \\
\hline potential experience & 5.9360 & 2.5205 & 6.1309 & 2.4688 \\
\hline \multirow[t]{2}{*}{ \# of indiv. } & 84378 & & 122708 & \\
\hline & \multicolumn{4}{|c|}{ all individuals in last wage (work) spell } \\
\hline age & 24.5537 & 2.6697 & 25.0175 & 2.9550 \\
\hline work experience & 3.7222 & 2.6672 & 3.6020 & 2.7811 \\
\hline time out of work & .4614 & .9945 & 1.1653 & 1.4199 \\
\hline potential experience & 4.8429 & 2.8220 & 4.8082 & 2.8231 \\
\hline \multirow[t]{2}{*}{ \# of indiv. } & \multirow{2}{*}{\multicolumn{4}{|c|}{$\begin{array}{c}14456 \\
\text { all individuals in last wage (work) spell } \\
\text { excluding individuals with zero years of time out of work }\end{array}$}} \\
\hline & & & & \\
\hline age & 24.8222 & 2.6947 & 25.4973 & 2.8313 \\
\hline work experience & 3.9004 & 2.6118 & 3.8596 & 2.7372 \\
\hline time out of work & .8874 & 1.2345 & 1.5425 & 1.4446 \\
\hline \# of indiv. & 5.4690 & 2.6465 & 5.2788 & 2.6802 \\
\hline potential experience & $7517(51 \%)$ & & $14806(75 \%)$ & \\
\hline
\end{tabular}

Note: Potential experience is calcuated as 1990 minus the year of entry into first employment after apprenticeship training. 
that men have accumulated almost three times as many years than women have; that is 1.16 years compared to 0.46 . One must note, however, that the latter comparison hides the fact, as illustrated in Figure 2, that women drop out of the sample and have not returned to work before 1991 which, once adjusted for, would lead to an increase of years in average time-out of work. Additionally, national service was compulsory for the period of 12 months for men in Germany between 1975 and 1990. This explains the relatively high share of males, 75 percent, who have ever been observed in a time out of work spell.

\subsection{Estimation results}

Estimation results of the wage regression are shown in Table 6 . In column one and two, we show the results using all cohorts in our sample. In column three and four, results for a highly selected group is shown, these are for the cohorts followed longest in our observation window are shown. Parameter estimates for the work experience variable reveal a time effect of the accumulation path. For males we find that most recently acquired work experience is remunerated relatively more than work experience acquired earlier. For females the decline is stronger. The return from experience seems to be higher for females than for males. Time out of work seems to have small effects on wages, that are partly negative. In the following we focus on the effect of timing of work experience on the wage gap. Therefore, we do not 
Table 6: Work history model for male and female workers: Fixed Effects Parameter Estimation Results of log wage regression model by sex

\begin{tabular}{|c|c|c|c|c|}
\hline & \multicolumn{2}{|c|}{ Cohorts 1975-1988 } & \multicolumn{2}{|c|}{ Cohorts 1975-1977 } \\
\hline & Females & Males & Females & Males \\
\hline $\begin{array}{l}\% \text { of year } \\
\text { spent working }\end{array}$ & & & & \\
\hline previous year & $\begin{array}{c}0.1133 \\
(17.82)^{* *}\end{array}$ & $\begin{array}{c}0.0432 \\
(12.30)^{* *}\end{array}$ & $\begin{array}{c}0.1238 \\
(7.21)^{* *}\end{array}$ & $\begin{array}{c}0.0644 \\
(9.51)^{* *}\end{array}$ \\
\hline 1 year ago & $\begin{array}{c}0.0921 \\
(17.65)^{* *}\end{array}$ & $\begin{array}{c}0.0412 \\
(12.89)^{* *}\end{array}$ & $\begin{array}{c}0.0935 \\
(6.64)^{* *}\end{array}$ & $\begin{array}{c}0.0440 \\
(7.32)^{* *}\end{array}$ \\
\hline 2 years ago & $\begin{array}{c}0.0499 \\
(10.48)^{* *}\end{array}$ & $\begin{array}{c}0.0485 \\
(17.38)^{* *}\end{array}$ & $\begin{array}{c}0.0302 \\
(2.59)^{* *}\end{array}$ & $\begin{array}{c}0.0409 \\
(8.03)^{* *}\end{array}$ \\
\hline 3 years ago & $\begin{array}{c}0.0608 \\
(11.59)^{* *}\end{array}$ & $\begin{array}{c}0.0309 \\
(10.35)^{* *}\end{array}$ & $\begin{array}{c}0.0331 \\
(2.76)^{* *}\end{array}$ & $\begin{array}{c}0.0241 \\
(4.67)^{* *}\end{array}$ \\
\hline 4 years ago & $\begin{array}{c}0.0449 \\
(7.64)^{* *}\end{array}$ & $\begin{array}{c}0.0249 \\
(7.72)^{* *}\end{array}$ & $\begin{array}{c}0.0624 \\
(4.95)^{* *}\end{array}$ & $\begin{array}{c}0.0226 \\
(4.27)^{* *}\end{array}$ \\
\hline 5 years ago & $\begin{array}{c}0.0611 \\
(8.91)^{* *}\end{array}$ & $\begin{array}{c}0.0332 \\
(8.75)^{* *}\end{array}$ & $\begin{array}{l}0.0310 \\
(2.46)^{*}\end{array}$ & $\begin{array}{c}0.0325 \\
(5.71)^{* *}\end{array}$ \\
\hline $6+$ years ago & $\begin{array}{c}0.0485 \\
(31.68)^{* *}\end{array}$ & $\begin{array}{c}0.0236 \\
(20.81)^{* *}\end{array}$ & $\begin{array}{c}0.0477 \\
(15.85)^{* *}\end{array}$ & $\begin{array}{c}0.0276 \\
(16.18)^{* *}\end{array}$ \\
\hline $\begin{array}{l}1 \text { if in } \\
\text { not working }\end{array}$ & & & & \\
\hline previous year & $\begin{array}{c}-0.0047 \\
(1.26)\end{array}$ & $\begin{array}{c}0.0110 \\
(4.71)^{* *}\end{array}$ & $\begin{array}{c}-0.0147 \\
(1.38)\end{array}$ & $\begin{array}{c}0.0133 \\
(3.03)^{* *}\end{array}$ \\
\hline 1 year ago & $\begin{array}{l}-0.0129 \\
(3.49)^{* *}\end{array}$ & $\begin{array}{c}-0.0048 \\
(2.06)^{*}\end{array}$ & $\begin{array}{l}-0.0383 \\
(3.89)^{* *}\end{array}$ & $\begin{array}{l}-0.0120 \\
(2.86)^{* *}\end{array}$ \\
\hline 2 years ago & $\begin{array}{l}-0.0204 \\
(6.76)^{* *}\end{array}$ & $\begin{array}{c}0.0068 \\
(3.74)^{* *}\end{array}$ & $\begin{array}{l}-0.0532 \\
(7.00)^{* *}\end{array}$ & $\begin{array}{l}-0.0067 \\
(1.99)^{*}\end{array}$ \\
\hline 3 years ago & $\begin{array}{c}-0.0046 \\
(1.41)\end{array}$ & $\begin{array}{c}-0.0020 \\
(1.06)\end{array}$ & $\begin{array}{l}-0.0345 \\
(4.50) * *\end{array}$ & $\begin{array}{l}-0.0129 \\
(3.79)^{* *}\end{array}$ \\
\hline 4 years ago & $\begin{array}{l}-0.0073 \\
(2.02)^{*}\end{array}$ & $\begin{array}{c}-0.0012 \\
(0.57)\end{array}$ & $\begin{array}{c}-0.0164 \\
(2.04)^{*}\end{array}$ & $\begin{array}{c}-0.0071 \\
(2.03)^{*}\end{array}$ \\
\hline 5 years ago & $\begin{array}{c}0.0022 \\
(0.53)\end{array}$ & $\begin{array}{c}0.0021 \\
(0.93)\end{array}$ & $\begin{array}{l}-0.0359 \\
(4.26)^{* *}\end{array}$ & $\begin{array}{c}-0.0048 \\
(1.30)\end{array}$ \\
\hline $6+$ years ago & $\begin{array}{c}0.0033 \\
(0.71)\end{array}$ & $\begin{array}{c}-0.0021 \\
(0.70)\end{array}$ & $\begin{array}{c}-0.0136 \\
(1.80)\end{array}$ & $\begin{array}{c}-0.0065 \\
(1.48)\end{array}$ \\
\hline $\begin{array}{l}\text { Time dummies included } \\
\text { constant }\end{array}$ & $\begin{array}{c}\text { yes } \\
3.7582 \\
(377.33)^{* *}\end{array}$ & $\begin{array}{c}\text { yes } \\
3.9789 \\
(594.70)^{* *}\end{array}$ & $\begin{array}{c}\text { yes } \\
3.6789 \\
(166.04)^{* *}\end{array}$ & $\begin{array}{c}\text { yes } \\
3.9881 \\
(420.42)^{* *}\end{array}$ \\
\hline$R^{2 *}$ & 0.3264 & 0.3074 & 0.20 & 0.29 \\
\hline \# observations & 71223 & 104668 & 12560 & 28422 \\
\hline \# individuals & 13462 & 17815 & 1557 & 2871 \\
\hline
\end{tabular}

Note: The dependent variable is the log of daily real wages. The wage observations come from 1981 to 1990. Absolute value of t-statistics in parentheses * significant at 5 percent level; ${ }^{* *}$ significant at 1 percent level. *: adjusted R-squared is reported, or within R-squared for fixed effects estimators. 
use the coefficients of the time out of work variables for calculation of the decomposition.

In Table 7 we summarise the decomposition of the wage gap at particular work experience levels using estimation results for the coefficients of the work experience variables. In panel A, we show the corresponding results. In the first column we list the raw gap. The gap increases slighly during the first and declines for workers with more than 4 years of experience. The gap due to timing of, and returns to experience, can be calculated by multiplying each individual's observed values for the vector of experience variables by the estimated coefficients for his or her gender and then by subtracting the women's average from the men's average. The gap due to timing is computed by multiplying each individual's values for the experience variables by the men's estimated coefficients, and we then subtract the women's average from the men's average. In this case both endowments and coefficients are held constant, and therefore timing of work experience is the sole source of wage gap. While the latter factor is unaffected by the coefficients from the female sample wage regression estimation, the former is affected. Hence, bias due to non-random selection of females into work is likely to affect these estimates. Results in Panel A seem to suggest that in the beginning of the career a quite high fraction is "explained" and its power declines and reverses sign. ${ }^{22}$ Furthermore, we find that timing of work

\footnotetext{
${ }^{22}$ Estimation of several models and estimators have shown that these estimates are
} 
Table 7: Decomposition of the male-female Wage Gap, based on estimates from table 6

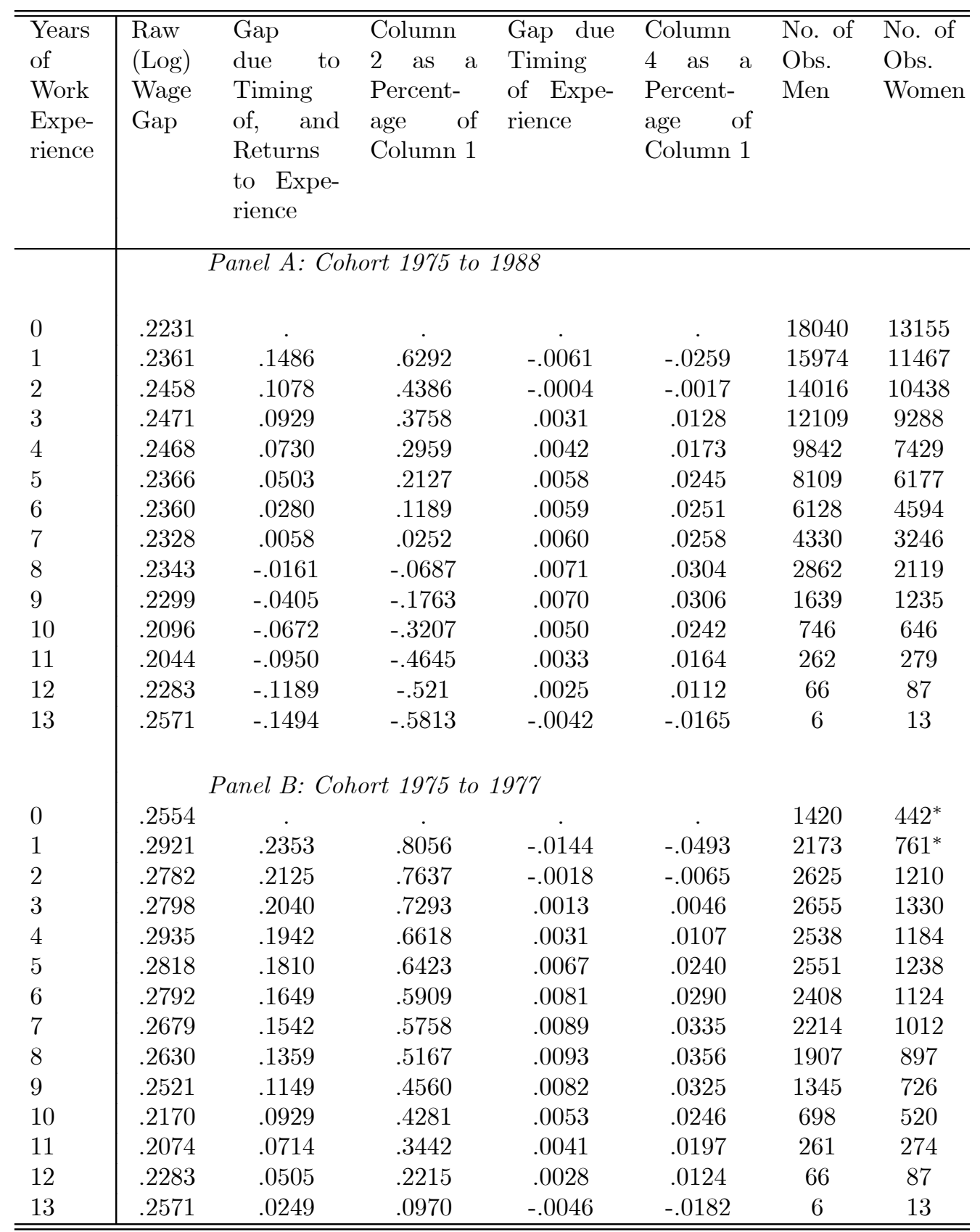

Note: ${ }^{*}$ Since we drop spells before 1981 for the wage regression estimations, we loose wage observations at low levels of experience for the cohorts 1975 to 1977. 
experience accounts for an increasing fraction of the gap. Among workers with 8 to 9 years of experience timing accounts for 3 percent.

For comparison, we present results for highly selected cohorts of workers with very similar education histories where selection bias should be most severe as could be seen from Figure 2. As reported in panel B of Table 7, for the cohorts 1975 to 1977 the raw gap seems a bit higher among those than at the mean. The evolution of the gap is slightly (more) concavely shaped. The timing effect is very similar to the average and varies between 0 or 1 percent in the beginning and increases to 3-4 percent at eight years of experience. In summary, the effect of timing becomes important between 5 to 9 years after completion of training. Hence, conditional on other factors, very early and later than 9 years after training interruptions of work are less harmful for wages.

\section{Conclusions}

We have examined male-female wage differentials during the early career using new administrative data for Germany. In the raw data we have found an entry wage gap of approximately 23 percent and an almost constantly high differential at a similar level all through the early career. The main findings are that premarket factors play an important role in determining the starting position of the career. In addition, for men and women at comhighly sensitive to the sample and specification. 
parable levels of experience, we find that the timing of the work experience matters but explains only 1 to 4 percent. The major part is unexplained.

These results show that within of group of those who go into apprenticeship training, pre-market choices of the particular training scheme are very important determinants of entry wages. Furthermore, differences in individual work histories are only of minor importance, at least during the first 8 years in the labour market. Our occupational qualification measure is very detailed in terms of human capital investment due to the nature of the German apprenticeship system and German labour markets that have been characterised as occupational labour markets in the literature.(Soskice (1994)). Hence, it is presumably highly correlated with productivity. With the data given we cannot answer, however, the question what exact fraction is due to productivity differences and other factors.

Evidence presented here underlines the great interest to study selection into education types and occupational careers further in order to measure wage effects of human capital types. This could shed more light on the permanently high wage differential during the early career we find for the main group of workers in Germany. For other countries where relatively small entry wage differentials and increasing male-female wage differentials over the early career have been documented, one may conjecture that selection has transitory effects on wages due to more frequent occupational changes. 


\section{References}

- Becker, Gary (1964): Human capital - A theoretical and empirical analysis with special reference to education, Chicago University Press, 3rd edition, 1993.

- Bender, Stefan, Jürgen Hilzendegen, Götz Rohwer and Helmut Rudolph (1996): Die IAB-Beschäftigtenstichprobe - 1975-1990, BeitrAB 197, Institut für Arbeitsmarkt- und Berufsforschung der Bundesanstalt für Arbeit, IAB, Nürnberg.

- Blau, Francine D. (1998): Trends in the well-being of American women, 1970-1995, Journal of Economic Literature, 26, pp.112-165.

- Blau, Francine D., and Marianne A. Ferber (1987): Discrimination: Empirical evidence from the United States, American Economic Review, $77(2)$, pp. 316-320.

- Blau, Francine, and Kahn, Lawrence M. (1997): Swimming upstream: Trends in the gender wage differential in the 1980s, Journal of Labor Economics, 15(1), pp.1-42.

- Bollinger, Christopher R. (1998): Measurement error in the current population survey: A nonparametric look, Journal of Labor Economics, 16(3), pp.576-594. 
- Dietz, Frido (1988): Strukturwandel auf dem Arbeitsmarkt, Mitteilungen aus der Arbeitsmarkt- und Berufsforschung, 21.Jg., IAB, Nürnberg.

- Dolton P.J., and Makepeace, G.H. (1986): Sample selection and malefemale earnings differentials in the graduate labour market, Oxford Economic Papers, 38, pp.317-341.

- Harkness, Susan (1996): The gender earnings gap: Evidence from the U.K., Fiscal Studies, 17(2), pp.1-36.

- Light, Audrey, and Ureta, Manuelita (1995): Early-career work experience and gender wage differentials, Journal of Labor Economics, 13(1), pp.121-154.

- Loprest, Pamela J. (1992): Gender differences in wage growth and job mobility, American Economic Review, 82(2), pp.526-532.

- Mincer; J. (1974): Schooling, experience and earnings, New York: Columbia University.

- Mincer, Jakob, and Haim Ofek (1982): Interrupted work careers: Depreciation and restoration of human capital, Journal of Human Resources, 17, pp.3-24.

- Mincer, J. and Polachek, S.W. (1974): Family investment in human 
capital: Earnings of women, Journal of Political Economy, 82, S76S108.

- Münch, Joachim (1992): Das Berufsbildungssystem in der Bundesrepublik Deutschland, European Centre for the Development of Vocational Training (CEDEFOP), Berlin.

- Neal, Derek A. and William R. Johnson (1996): The role of premarket factors in black-white wage differences, Journal of Political Economy, 104(5), pp.869-895.

- O’Neill, June, and Polachek, Solomon (1993): Why the gender gap in wages narrowed in the 1980s, Journal of Labor Economics, 11(1), pp.205-228.

- Polachek, Solomon W. (1981): Occupational self-selection: A human capital approach to sex differences in occupational structure, Review of Economics and Statistics, 1981, pp.60-69.

- Soskice, David (1994): Reconciling markets and institutions: The German apprenticeship system, in Lynch, L., editor, Training and the private sector - International comparisons, University of Chicago Press for NBER, Chicago, pp.25-60. 


\begin{tabular}{|c|c|c|}
\hline \multicolumn{3}{|c|}{ Appendix: Summary of selection of data sample } \\
\hline Selection rule & sample of males & sample of females \\
\hline original sample: & & \\
\hline \# of observations & 265.098 & 209.900 \\
\hline (\# of individuals ) & $(25.020)$ & $(25.020)$ \\
\hline part time: & & \\
\hline \# of observations & -8.422 & -39.138 \\
\hline (\# of individuals ) & $(-688)$ & $(-3.218)$ \\
\hline higher education: & & \\
\hline \# of observations & -39.604 & -21.942 \\
\hline (\# of individuals ) & $(-3.208)$ & $(-1.944)$ \\
\hline analysis sample: & 17017 & $14000-700107$ \\
\hline $\begin{array}{l}\text { total \# of observations } \\
\text { (total \# of individuals) }\end{array}$ & $\begin{aligned} 217.072 & =81.97 \% \\
(21.124 & =84.5 \%)\end{aligned}$ & $\begin{aligned} 148.820 & =70.91 \% \\
(15.267 & =74.8 \%)\end{aligned}$ \\
\hline
\end{tabular}




\section{IZA Discussion Papers}

\begin{tabular}{|c|c|c|c|c|}
\hline No. & Author(s) & Title & Area & Date \\
\hline 609 & G. Saint-Paul & Cognitive Ability and Paternalism & 3 & $10 / 02$ \\
\hline 610 & A. Heitmueller & $\begin{array}{l}\text { Unemployment Benefits, Risk Aversion, and } \\
\text { Migration Incentives }\end{array}$ & 4 & $10 / 02$ \\
\hline 611 & G. Saint-Paul & $\begin{array}{l}\text { Some Thoughts on Macroeconomic Fluctuations } \\
\text { and the Timing of Labor Market Reform }\end{array}$ & 3 & $10 / 02$ \\
\hline 612 & $\begin{array}{l}\text { J. J. Dolado } \\
\text { M. Jansen } \\
\text { J. F. Jimeno }\end{array}$ & $\begin{array}{l}\text { A Matching Model of Crowding-Out and On-the- } \\
\text { Job Search (with an Application to Spain) }\end{array}$ & 2 & $10 / 02$ \\
\hline 613 & $\begin{array}{l}\text { P. Kuhn } \\
\text { M. Skuterud }\end{array}$ & $\begin{array}{l}\text { Internet Job Search and Unemployment } \\
\text { Durations }\end{array}$ & 5 & $10 / 02$ \\
\hline 614 & M. Pannenberg & $\begin{array}{l}\text { Long-Term Effects of Unpaid Overtime: } \\
\text { Evidence for West Germany }\end{array}$ & 1 & $10 / 02$ \\
\hline 615 & W. Koeniger & $\begin{array}{l}\text { The Dynamics of Market Insurance, Insurable } \\
\text { Assets, and Wealth Accumulation }\end{array}$ & 3 & $10 / 02$ \\
\hline 616 & $\begin{array}{l}\text { R. Hujer } \\
\text { U. Blien } \\
\text { M. Caliendo } \\
\text { C. Zeiss }\end{array}$ & $\begin{array}{l}\text { Macroeconometric Evaluation of Active Labour } \\
\text { Market Policies in Germany - A Dynamic Panel } \\
\text { Approach Using Regional Data }\end{array}$ & 6 & $10 / 02$ \\
\hline 617 & $\begin{array}{l}\text { L. Magee } \\
\text { M. R. Veall }\end{array}$ & $\begin{array}{l}\text { Allocating Awards Across Noncomparable } \\
\text { Categories }\end{array}$ & 1 & $10 / 02$ \\
\hline 618 & $\begin{array}{l}\text { A. L. Booth } \\
\text { M. Francesconi } \\
\text { G. Zoega }\end{array}$ & $\begin{array}{l}\text { Oligopsony, Institutions and the Efficiency of } \\
\text { General Training }\end{array}$ & 6 & $10 / 02$ \\
\hline 619 & $\begin{array}{l}\text { H. Antecol } \\
\text { D. A. Cobb-Clark }\end{array}$ & $\begin{array}{l}\text { The Changing Nature of Employment-Related } \\
\text { Sexual Harassment: Evidence from the U.S. } \\
\text { Federal Government (1978-1994) }\end{array}$ & 5 & $10 / 02$ \\
\hline 620 & D. A. Cobb-Clark & $\begin{array}{l}\text { Public Policy and the Labor Market Adjustment } \\
\text { of New Immigrants to Australia }\end{array}$ & 1 & $10 / 02$ \\
\hline 621 & G. Saint-Paul & On Market Forces and Human Evolution & 5 & $11 / 02$ \\
\hline 622 & $\begin{array}{l}\text { J. Hassler } \\
\text { J. V. Rodriguez Mora }\end{array}$ & Should UI Benefits Really Fall Over Time? & 3 & $11 / 02$ \\
\hline 623 & $\begin{array}{l}\text { A. R. Cardoso } \\
\text { P. Ferreira }\end{array}$ & $\begin{array}{l}\text { The Dynamics of Job Creation and Destruction } \\
\text { for University Graduates: Why a Rising } \\
\text { Unemployment Rate Can Be Misleading }\end{array}$ & 1 & $11 / 02$ \\
\hline 624 & $\begin{array}{l}\text { J. Wagner } \\
\text { R. Sternberg }\end{array}$ & $\begin{array}{l}\text { Personal and Regional Determinants of } \\
\text { Entrepreneurial Activities: Empirical Evidence } \\
\text { from the REM Germany }\end{array}$ & 1 & $11 / 02$ \\
\hline 625 & F. Galindo-Rueda & $\begin{array}{l}\text { Endogenous Wage and Capital Dispersion, On- } \\
\text { the-Job Search and the Matching Technology }\end{array}$ & 3 & $11 / 02$ \\
\hline 626 & A. Kunze & $\begin{array}{l}\text { Gender Differences in Entry Wages and Early } \\
\text { Career Wages }\end{array}$ & 5 & $11 / 02$ \\
\hline
\end{tabular}

An updated list of IZA Discussion Papers is available on the center's homepage www.iza.org. 